\title{
THE INFLUENCE OF PRACTICUM-BASED OUTDOOR INQUIRY MODEL ON SCIENCE PROCESS SKILLS IN LEARNING PHYSICS
}

\author{
Yeni Ristya Wardani*1, Mundilarto², Jumadi³, Insih Wilujeng ${ }^{4}$, Heru Kuswanto ${ }^{5}$, Dwi Puji \\ Astuti $^{6}$ \\ 1,2,3,4,5 Postgraduate Program of Physics Education, Yogyakarta State University, Indonesia \\ ${ }^{6}$ State Senior High School 1 Sleman, Yogyakarta, Indonesia \\ *Correspondence address: yennyristya @ gmail.com
}

Received: January $7^{\text {th }}, 2019$. Accepted: April 12 $2^{\text {nd }}, 2019$. Published: April 29, 2019

\begin{abstract}
The main purpose of this study is to find out the influence of practicum-based outdoor inquiry model on science process skills. Quasi-experiment design was employed as the research method by Matching Only Post-test Control Group. The research sample was taken using a cluster sampling technique. The samples consisted of experimental class (XI MIA 1) in a total of 25 students treated with practicum-based outdoor inquiry model. The control class (XI MIA 3) consisted of 29 students treated with direct instruction model. In collecting the data, essay test was used in the form of worksheets containing the aspect of science process skills of formulating hypotheses, designing experiment, interpreting data into tables, and drawing a conclusion (inferring). The study results demonstrate that practicum-based outdoor inquiry model was effective in improving the science process skills. It was shown in p-value (significant) of 0.00. The implication of this study is the need to design a practicum-based outdoor inquiry model by noticing what skills are going to improve by means of more varied outdoor activities.
\end{abstract}

C2019 Physics Education, UIN Raden Intan Lampung, Indonesia

Keywords: learning physics, practicum-based outdoor inquiry, science process skills

\section{INTRODUCTION}

Outdoor learning model can be one of the ways to induce a sense of care toward surroundings and generate a sense of curiosity that will be the link to the realitybased solution discovery based in solving problems (Ampuero, Miranda, Delgado, Goyen, \& Weaver, 2015). Problems that are found and dealt with in real life can be such a learning material in conducting direct field investigation (Maulidiyahwarti, Sumarmi, \& Amirudin, 2016). Outdoor learning is able to explore teachers' and students' abilities in scientific investigation efforts by utilizing the unlimited technology in the form of their environment (Kali, Levy, Levin-peled, \& Tal, 2018).

The process of outdoor learning can generate the opportunity to develop a student's critical thinking (Christie, Beames, \& Higgins, 2016). Outdoor learning application is able to develop science process skills and problem-solving ability (Wahyuni, Indrawati, Sudarti, \& Suana, 2017).

Problem-solving through inquiry will lead the participants to the sense of curiosity and student's high thinking ability in finding information (Maulidiyahwarti, Sumarmi, \& Amirudin, 2016). A sense of curiosity is not simply in forms of facts, concepts, and principles, but also including formal and informal processes in the discovery which are able in generating practicum activities $(\mathrm{Wu}$, Jen, Kuo, Hsu, \& Wu, 2018). Physics learning through practicum activities with the help from discovery-based practicum guidelines is able in developing students' thinking skills (Sulistiyono, Mundilarto, \& Kuswanto, 2017).

Learning physics can be done by using direct instruction model that is oriented in syntax, presentations, and phases of structured exercise and independent 
exercises (Kanfush, 2014). Direct instruction model is a learning model that emphasizes gradual mastery of the concept and learning materials. Some weaknesses of direct instructions are, among others, (1) depending on teacher's ability as a central role, (2) only emphasizing on listening, observing, and taking note for student's skills, (3) not involving much student's role thus only a little portion of material delivered can be remembered or memorized, and (4) evoking student's sense of boredom (Prastowo, 2013).

Learning physics through guided inquiry learning model has a positive influence on improving science process skills and the results of learning physics itself (Iswatun, Mosik, \& Subali, 2017). Learning physics with the motivation of finding the facts is determined by the presence of four behavioral aspects, i.e. attention, relevance, self-confidence, and satisfaction (Sari, Sunarno, \& Sarwanto, 2018). Student's motivation will increase by connecting the concepts of physics with their real lives and their surrounding environment (Holubova, 2015).

Learning processes will be interesting, enthusiastic, and will familiarize the students with to work scientifically through the learning process of finding facts (inquiry) from their surrounding environment (outdoor) (Hakim, Suparmi, \& Masykuri, 2017). Also, outdoor learning can be applied in sustainable ways into the school curriculum as one of the challenges for the teacher's exploration (Remington \& Legge, 2016). Fact-finding process (inquiry) supports student's mastery of concepts that will lead to a positive result in student's better achievement (Mupira \& Ramnarain, 2018).

Improved process skills can be achieved and trained by means of practicum-based learning (Hidayah, Arifuddin, \& Mahardika, 2017). Through practicum activities, students are given with bigger opportunity to explore science process skills like formulating and testing hypotheses (Liandari, Siahaan, Kaniawati, \& Isnaini, 2017). The result of science process skills can be measured by using a test instrument on science process skills (Noor \& Wilujeng, 2015). Process skill performances, i.e., skills to observe, predict, conduct experiment, measure, and communicate, are measured by using an instrument of observation assessment sheet (Supahar, Rosana, Ramadani, \& Kurnia Dewi, 2017).

Three basic science process skills are observing, measuring, and using practicum equipment (Juhji, 2016). Whereas, four skills are predicting the data (hypothesizing), interpreting the data, communicating, and inferring the data. One of study result stated that the skills of predicting, interpreting, communicating, and inferring the data were still considered low thereby students still face difficulty for performing higher thinking in solving problems (Juhji, 2016).

The problem of low science process skills can be solved by using inquiry learning model (Iswatun et al., 2017). Students are able to transfer better the information they gathered and to better explore information independently and extensively through this inquiry learning (Sheftyawan, Prihandono, \& Lesmono, 2018). Improving student's science process skills can be achieved by applying the combination of guided inquiry model of learning and STAD (Erina \& Kuswanto, 2015).

Improved science process skills can be obtained by implementing the inquiry model in combination with physics practicum on the subject of real-virtual images (Puji Hartini, 2017). By means of experiment method with the guided inquiry, student's process skills of observing, conducting an experiment, communicating, predicting and inferring increased significantly (Subekti \& Ariswan, 2016).

One of the subject matters in Physics that has led to misconception is the concept 
of optics (Suwarna, 2013; Agnes, Kaniawati, \& Danawan, 2015). Identification showed that the highest misconception is about magnifying glass, while the lowest one is about microscope and telescope (Munawaroh \& Setyarsih, 2016). In addition, students still have a misconception about image formation and image properties on positive lenses (Sheftyawan, Prihandono, \& Lesmono, 2018). Therefore, from the problem identification result, it requires a follow up so that process skills and student's learning result can be improved, especially about the optics subject matter in the sub-chapter of a magnifying glass.

The observation result on the learning process in State Senior High School 1 Sleman (SMA N 1 Sleman) revealed that teachers used direct instruction model with laboratory practicum method. Most of the students got world-weary as the practicum was conducted only in the laboratory. Moreover, the laboratory facilities were still less optimal in supporting the learning process. The constraint of laboratory facilities became the main problem that hindered process skill improvement. Therefore, it requires a strategy for not only conducting practicum in the laboratory. SMA N 1 Sleman has a landscape that is highly supportive of outdoor learning activities. This school has a big yard, some gazebos, and some parks surround them which are located close to classes. The teachers apply outdoor inquiry as one way of making students more active during the learning process to improve their process skills.

The purpose of this study was to find out the application of outdoor inquiry model combined with practicum activities on improving science process skills. Aspects of process skills being improved in this study were formulating hypotheses, designing outside-the-class experiment (outdoor activities), interpreting data into tables, and drawing a conclusion (inferring).

\section{METHOD}

As a quantitative study, it employed a research method of quasi-experiment by using the matching only posttest control group. It was conducted in SMA N 1 Sleman in the school year of 2017/2018. Cluster sampling was chosen as sample taking technique.

Research subjects consisted of two classes, i.e. Class XI MIA 1 as experiment class and XI MIA 3 as control class. The numbers of research subjects for the experiment class were 25 students, whereas the control class was 29 students.

Variables of science process skills were assessed based on student's answers on Student Worksheet (SW). These student worksheets contained the subject matter of magnifying glass. The student worked on the SW individually, even though the practicum was done collectively. Before given for field testing, SW had been validated by experts in this subject. It resulted in an assessment data that the SW instrument on magnifying glass subject matter had been used without revision with score details for content aspect was categorized very good (score 4 ), and language aspect was very good (score 5). Table 1 presents the design of the matching only posttest control group.

Table 1. The Matching Only Posttest Control Group

\begin{tabular}{cccc} 
Class & Matching & Treatment & Posttest \\
\hline Experiment & $\mathrm{M}$ & $\mathrm{X}$ & $\mathrm{O}$ \\
Control & $\mathrm{M}$ & $\mathrm{K}$ & $\mathrm{O}$
\end{tabular}

Description :

$\mathrm{X}=$ practicum-based outdoor inquiry model

$\mathrm{K}=$ direct instruction model

$\mathrm{O}=$ science process skills

Research variables comprised of independent and dependent variables. Practicum-based outdoor inquiry model and direct instruction model constituted the independent variables. Meanwhile, science process skills were the dependent variables.

The following Table 2 outlines the assessment rubric for science process skill aspect. 
Table 2. Assessment Rubric for Science Process Skill (SPS) Aspects (Maradona, 2013)

\begin{tabular}{|c|c|c|c|}
\hline No & SPS & SPS Indicators & Score \\
\hline 1 & $\begin{array}{l}\text { Formulating } \\
\text { hypotheses }\end{array}$ & $\begin{array}{l}\text { 1. Formulating rational hypotheses } \\
\text { 2. Hypotheses that use concepts, theories, } \\
\text { and laws } \\
\text { 3. Hypotheses are in accordance with the } \\
\text { purpose of the experiment } \\
\text { 4. Using good and correct language, as well } \\
\text { as logical }\end{array}$ & $\begin{array}{l}\text { Score } 4 \text { if } 4 \text { indicators are met } \\
\text { Score } 3 \text { if } 3 \text { indicators are met } \\
\text { Score } 2 \text { if } 2 \text { indicators are met } \\
\text { Score } 1 \text { if } 1 \text { indicator is met } \\
\text { Score } 0 \text { if } 0 \text { indicators are met }\end{array}$ \\
\hline 2 & $\begin{array}{l}\text { Designing an } \\
\text { experiment }\end{array}$ & $\begin{array}{l}\text { 1. The student is able to find suitable } \\
\text { equipment and materials with the } \\
\text { experiment } \\
\text { 2. Students are able to design an experiment } \\
\text { 3. Able to make systematical and coherent } \\
\text { experiment procedures } \\
\text { 4. Using good and correct language }\end{array}$ & $\begin{array}{l}\text { Score } 4 \text { if } 4 \text { indicators are met } \\
\text { Score } 3 \text { if } 3 \text { indicators are met } \\
\text { Score } 2 \text { if } 2 \text { indicators are met } \\
\text { Score } 1 \text { if } 1 \text { indicator is met } \\
\text { Score } 0 \text { if } 0 \text { indicators are met }\end{array}$ \\
\hline 3 & $\begin{array}{l}\text { Interpreting the } \\
\text { data }\end{array}$ & $\begin{array}{l}\text { 1. Combining all information from various } \\
\text { theories with the experiment results } \\
\text { 2. Connecting between variables } \\
\text { 3. Discovering the pattern of observation } \\
\text { results } \\
\text { 4. Putting the experiment data into suitable } \\
\text { tables }\end{array}$ & $\begin{array}{l}\text { Score } 4 \text { if } 4 \text { indicators are met } \\
\text { Score } 3 \text { if } 3 \text { indicators are met } \\
\text { Score } 2 \text { if } 2 \text { indicators are met } \\
\text { Score } 1 \text { if } 1 \text { indicator is met } \\
\text { Score } 0 \text { if } 0 \text { indicators are met }\end{array}$ \\
\hline 4 & $\begin{array}{l}\text { Inferring } \\
\text { (drawing } \\
\text { conclusion) }\end{array}$ & $\begin{array}{l}\text { 1. Conclusions are in accordance with the } \\
\text { experiment results } \\
\text { 2. Linking tendency between variables } \\
\text { 3. Related to experiment hypotheses } \\
\text { 4. Using language inappropriate with physics } \\
\text { concepts }\end{array}$ & $\begin{array}{l}\text { Score } 4 \text { if } 4 \text { indicators are met } \\
\text { Score } 3 \text { if } 3 \text { indicators are met } \\
\text { Score } 2 \text { if } 2 \text { indicators are met } \\
\text { Score } 1 \text { if } 1 \text { indicator is met } \\
\text { Score } 0 \text { if } 0 \text { indicators are met }\end{array}$ \\
\hline
\end{tabular}

Data collection was carried out by using an essay test in Student Worksheet (SW). The essay test and observation sheet contained assessment rubric for science process skill indicators being studied. Data was gathered when the practicum process was taking place. Students conducted practicum activity on Magnifying glass subject matter through some activities steps in accordance with inquiry outdoor model syntax. Table 3 presents outdoor inquiry model syntax as follow.

Table 3. Outdoor Inquiry Model Syntax

\begin{tabular}{llllll} 
& \multicolumn{5}{c}{ Outdoor Inquiry } \\
\multicolumn{1}{c}{ Science Process Skills } & \multicolumn{5}{c}{ Phases } \\
& 1 & 2 & 3 & 4 & 5 \\
\hline Formulating Hypotheses & $\mathrm{v}$ & $\mathrm{v}$ & & & \\
Designing an experiment & & & $\mathrm{v}$ & $\mathrm{V}$ & \\
Integrating data into tables & & & & $\mathrm{v}$ & \\
Inferring conclusion & & & & & $\mathrm{v}$ \\
\hline
\end{tabular}

Description:

Phase 1: Problem orientation

Phase 2: Hypotheses formulation
Phase 3: Data collection

Phase 4: Hypotheses testing

Phase 5: Data analysis

The next step was that students completed the essay test in their Student Worksheet (SW) that contained problems or items had been adjusted to science process skills being assessed. The following Table 4 shows the reference scale for SW assessment (Widoyoko, 2014)

Table 4. Four Criteria Scale of Assesment

\begin{tabular}{cc}
\hline $\begin{array}{c}\text { The range of average } \\
\text { score }\end{array}$ & Category \\
\hline $\mathrm{X}>3,25$ & Very Good \\
$2,50<\mathrm{X} \leq 3,25$ & Good \\
$1,75<\mathrm{X} \leq 2,50$ & Sufficient \\
$1,00<\mathrm{X} \leq 1,75$ & Not Good \\
\hline (Widoyoko, 2014) &
\end{tabular}

Score achievement results for science process skills, both for control class and experiment class, were tested by means of Independent Sample t-Test and One- 
Sample t-Test by employing SPSS 17.0. Independent Sample t-Test means that significant value of $<0,05$ can be concluded that $H_{O}$ is rejected and $H_{1}$ is accepted. It indicates that there is a difference in science process skill results between experiment class and control class. Meanwhile, the learning model is said as effective when p-value (significance) is $<0.05$ in One-Sample tTest.

\section{RESULTS AND DISCUSSION}

According to the experts of learning instrument, validation result for Student Worksheet on Magnifying glass subject matter that can be presented is content and language aspects. The score for content aspect is 4 and score for language aspect is 5. All aspects are categorized as very good. Table 5 is the results of science process skills for those two classes (control class and experiment class).

Table 5. Results of Science Process Skills

\begin{tabular}{lcc}
\multicolumn{1}{c}{$\begin{array}{c}\text { Aspects of Science } \\
\text { Process Skills }\end{array}$} & $\begin{array}{c}\text { Control } \\
\text { Class }\end{array}$ & $\begin{array}{c}\text { Experiment } \\
\text { Class }\end{array}$ \\
\hline Formulating hypotheses & 2,27 & 3,32 \\
Designing an experiment & 2,23 & 3,20 \\
$\begin{array}{l}\text { Interpreting data into a } \\
\text { table }\end{array}$ & 2,27 & 3,40 \\
Inferring conclusion & 2,60 & 3,36 \\
\hline
\end{tabular}

The following is a further detailed explanation for the results of science process skills in Table 5 presented above.

\section{Science Process Skills}

1. Formulating Hypotheses

From Table 5, it can be seen that the result of science process skill of formulating hypotheses for control class was 2.27 (categorized as sufficient), whereas for experiment class was 3.32 (very good). Both of these results demonstrate that practicum-based outdoor inquiry learning model was more effective compared with the conventional model in drilling student's skill in formulating hypotheses. In this case, students in the experiment class had the aspect of science process skill in formulating hypotheses. The students were able to predict what phenomenon was going to happen based on the problem given in problem orientation. The following is Figure 1 that comprises the student's answer sheet in experiment class in formulating hypotheses

\section{MENYUSUN HIPOTESIS}

Untuk membuat hipotesis kalian harus menganalisis pernyataan dari permasalahan di atas.

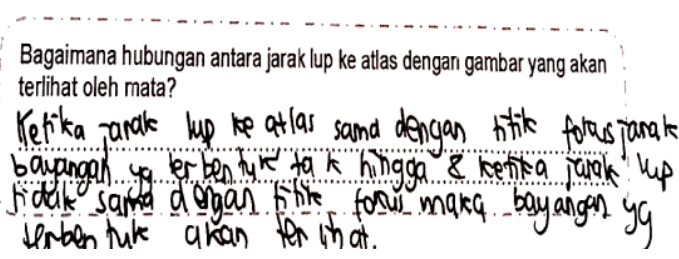

Figure 1. Student's answer sheet in formulating hypotheses

2. Designing an experiment

It shows in Table 5 that the ability to design an experiment for control class was 2.23 (categorized as sufficient), while for experiment class was 3.20 (good). This indicates that students in the experiment class, after joining the practicum-based outdoor inquiry learning model, employed the experiment in a logical way in accordance with the concepts in physics. They were also able to identify control variables and dependent variables in accord with the experiment they were designing. The following Figure 2 shows student's answer sheet in experiment class in designing experiment. 


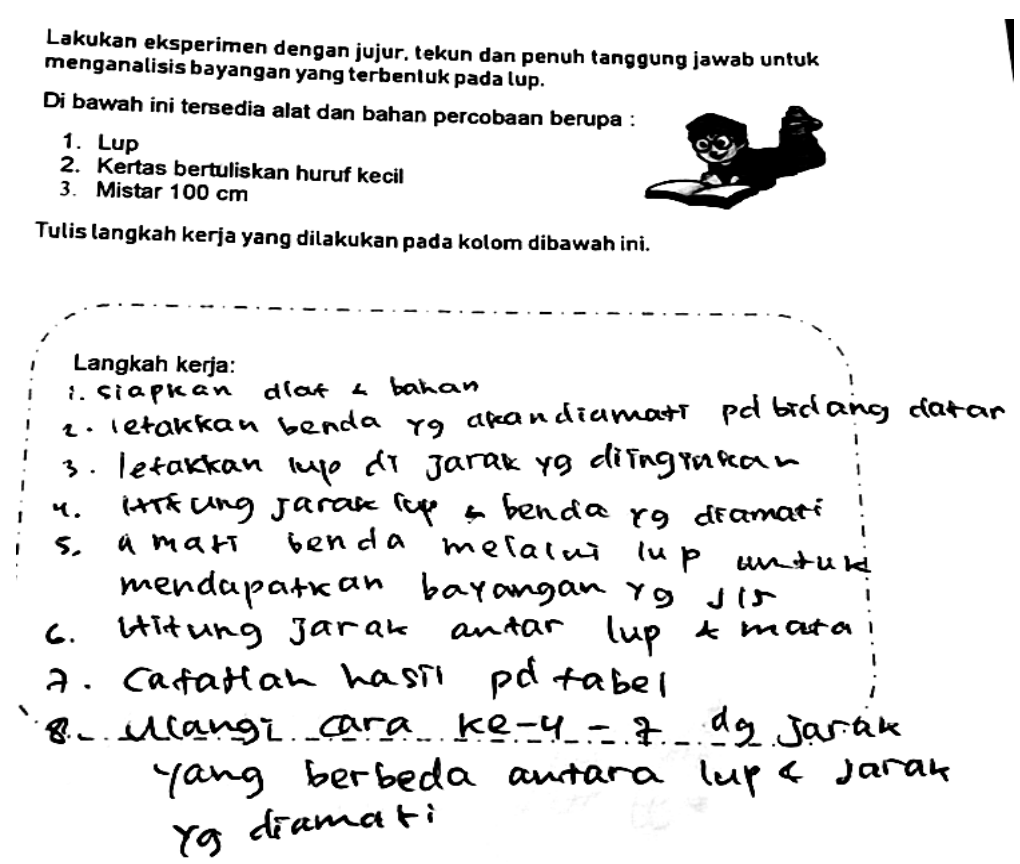

Figure 2. Student's answer sheet in designing an experiment

3. Interpreting data into a table

As shown in Table 5, the aspect of interpreting data into a table for control class was 2.27 (categorized as good), while for experiment class was 3.40 (categorized as very good). This exhibits that students in the experiment class, after conducting an experiment

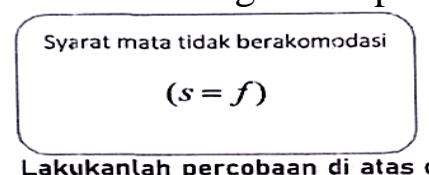

Lakukanlah percobaan di atas dengan menggunakan alat-alat yang telah disediakan dan catatlah data yang diperoleh dalam tabel!

Data Hasil Pengamatan based on their experiment design, were able to integrate the numbers of experiment results into tables in the appropriate measured quantity. Figure 3 below is the student's answer sheet in interpreting data into the table.

\begin{tabular}{|c|c|c|c|c|}
\hline No & $\begin{array}{c}\text { Jarak benda } \\
\text { terhadap lup (cm) }\end{array}$ & $\begin{array}{c}\text { Jarak lup terhadap } \\
\text { mata (cm) }\end{array}$ & $\begin{array}{c}\text { Jarak fokus } \\
(\mathrm{cm})\end{array}$ & $\begin{array}{c}\text { Mata berakomodasi } \\
\text { Jmata tidak } \\
\text { berakomodasi }\end{array}$ \\
\hline 1 & $10 \mathrm{~cm}$ & $20 \mathrm{~cm}$ & $6.67 \mathrm{~cm}$ & Berakomodasi \\
\hline 2 & $11 \mathrm{~cm}$ & $28 \mathrm{~cm}$ & $7,9 \mathrm{~cm}$ & Berakomodasi \\
\hline 3 & $8 \mathrm{~cm}$ & $17 \mathrm{~cm}$ & $5.44 \mathrm{~cm}$ & Tidak berakomodosi \\
\hline 4 & $9 \mathrm{~cm}$ & $41 \mathrm{~cm}$ & $7.38 \mathrm{~cm}$ & Tidak berakomodasi \\
\hline
\end{tabular}

Figure. 3. Student's Answer Sheet in Interpreting Data into Table

4. Inferring conclusion

Table 5 shows the result of inferring skill for control class was 2.6 (categorized as good), whereas for experiment class was 3.36 (categorized as very good). It reveals that students who experienced a practicum-based outdoor inquiry learning process were able to create ideas from observation. They had been trained in inferring ideas from object condition based on concepts in Physics. The following Figure 4 presents the student's answer sheet in drawing a conclusion (inferring). 
1. Hitunglah perbesaran bayangan berdasarkan data yang diperoleh

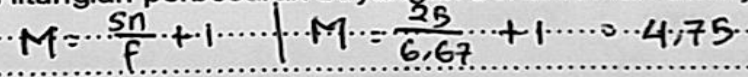

2. Berdasarkan data hasil pengamatan, apa yang terjadi jika jarak lup dengan tulisan semakin dekat? gambar terithat semakin jelas dan Mer besarannya semaicin kecr!

3. Apa yang terjadi jika jarak lup dengan tulisan semakin jauh? gambar terlihal semalcrn buram serta per besarannya semaicin besar.

4. Bagaimana hubungan bayangan yang teramati dengan letak benda terhadap lup?

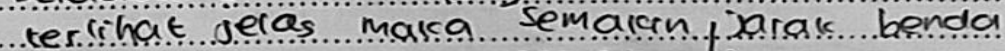
terhadap lup mala semakin besar jarak lup terhadap mata.

Figure. 4. Student's Answer Sheet in Drawing Conclusion (Inferring)

As to t-test result for science process skill score, SPSS17.0 was employed. Table 6 presents the t-test results for Science Process Skills (SPS) by using SPSS 17.0.

Table 6. T-test for Science Process Skills

\begin{tabular}{cccc}
\hline & $\mathrm{t}$ & Sig (2-tailed) & $\begin{array}{c}\text { Std. } \\
\text { Differences } \\
\text { Error }\end{array}$ \\
\hline SPS & 10.646 & .000 & 1.945 \\
& 10.781 & .000 & 1.920 \\
\hline
\end{tabular}

T-test results for Science Process Skills score by using SPSS 17.0.

$H_{O}=$ there is no difference in science process skill results between experiment class and control class

$H_{1}=$ there is a difference in science process skill results between experiment class and control class

As presented in Table 6, significance value (2-tailed) $=0.000$. This result interprets the significance value of $<0.05$. Therefore, it can be inferred that $H_{O}$ is rejected and $H_{1}$ is accepted. This means that there is a difference in science process skill results between experiment class and control class. It also can be seen from the T-test result that significance value (2tailed) for experiment class was 0.000 which means that practicum-based inquiry model for learning was effectively applied in this experiment class.

Each converted value was further tested with One Sample t-Test as shown in Table 7 in order to discover the effectiveness of the learning model in those two classes. This table was the result of one sample tTest for Control Class and Experiment Class.

Table 7. One Sample t-Test in the Control Class and Experiment Class

\begin{tabular}{ccc}
\hline Category & $\begin{array}{c}\text { Control } \\
\text { Class }\end{array}$ & $\begin{array}{c}\text { Experiment } \\
\text { Class }\end{array}$ \\
\hline Sig. (2-tailed) & .835 & .000 \\
\hline
\end{tabular}

Based on the analysis results of Independent Sample t-Test by means of SPSS 17.0, Table 7 shows that significance level $(2$-tailed $)=0,000$. These results interpret the significance of $<0.05$. The $t-$ Test results in this table demonstrate that science process skills for students in experiment class was sig (2-tailed) of 0.000 , means that practicum-based inquiry model for learning was effectively applied in this experiment class.

Means score of science process skills for experiment class was 3.32 (categorized as very good), whereas the means score of science process skills for the control class was 2.47 (or categorized as sufficient). These results are in line with the other 
studies stating that science process skills were increasing after applying inquiry model (Rahmasiwi, Santosari, \& Sari, 2015) and learning through experiment method (Ratunguri, 2016).

Aspects of science process skills like formulating hypotheses, interpreting data, and inferring conclusion were categorized as good, with skill in designing experiment was categorized as very good. The enhancement of those aspects of science process skills was supported by study results asserting that practicum-based inquiry model for learning was more effective in improving science process skills, more particularly for aspects of designing an experiment and formulating hypotheses (I. Risnawati, I. Kaniawati, 2013)

\section{CONCLUSION}

Practicum-based inquiry model for learning is effective in improving science process skills in learning Physics. It is indicated from a $p$-value of science process skills for experiment class was $<0.05$, i.e. 0.000 .

\section{REFERENCES}

Agnes, D., Kaniawati, I., \& Danawan, A. (2015). Analisis Deskriptif Tes Tiga Tingkat Materi Optika Geometri dan Alat Optik. In Simposium Nasional Inovasi dan Pembelajaran Sains 2015 (SNIPS 2015), 597-600. Bandung, Indonesia: Institut Teknologi Bandung. Retrieved from http://portal.fmipa.itb.ac.id/snips201 5/files/snips_2015_dea_agnes_5d $21 \mathrm{f}$ c10e01072cdc9178de0e48bc508.pdf

Ampuero, D., Miranda, C. E., Delgado, L. E., Goyen, S., \& Weaver, S. (2015). Empathy and critical thinking: Primary students solving local environmental problems through outdoor learning. Journal of Adventure Education and Outdoor Learning, 15(1), 64-78. https://doi.org/10.1080/14729679.20

\subsection{7}

Christie, B., Beames, S., \& Higgins, P. (2016). Context, culture and critical thinking: Scottish secondary school teachers' and pupils ' experiences of outdoor learning. British Educational Research Journal, 42(3), 417-437. https://doi.org/10.1002/berj.3213

Erina, R., \& Kuswanto, H. (2015). Pengaruh Model Pembelajaran STAD Terhadap Keterampilan Proses Sains dan Hasil Belajar Kognitif Fisika Di SMA. Jurnal Inovasi Pendidikan IPA, $\quad$ 1(2), 202-211. https://doi.org/10.21831/jipi.v1i2.75 07

Hakim, L., Suparmi, \& Masykuri, M. (2017). Pengembangan Perangkat Pembelajaran Fisika Berbasis Empat Pilar Pendidikan Melalui OutdoorInquiry Untuk Meningkatkan Kebiasaan Bekerja Ilmiah Pada Materi Momen Gaya, Fluida, Dan Keseimbangan Statis Di IKIP PGRI Pontianak. Jurnal Inkuiri UNS, 6(3), 153-162. Retrieved from ttp://dx.doi.org/10.20961/inkuiri.v6i3 .17868

Hidayah, N., Arifuddin, M., \& Mahardika, A. I. (2017). Meningkatkan Keterampilan Proses Sains Pada Pembelajaran Fisika Menggunakan Metode Percobaan. Berkala Ilmiah Pendidikan Fisika, 5(2), 198-212. https://doi.org/10.20527/bipf.v5i2.29 14

Holubova, R. (2015). Environmental Education - A Model of the Gulf Stream. American Journal of Educational Research, 2015, Vol. 3, No. 8, 1057-1061 Available Online at Http://Pubs.Sciepub.Com/Education/ 3/8/18 (C) Science and Education Publishing DOI:10.12691/Education-3-8-18

Environmental, 3(8), 1057-1061. https://doi.org/10.12691/education-38-18

I. Risnawati, I. Kaniawati, R. E. (2013). 
Efektivitas Penerapan Model Pembelajaran Inkuiri Berbasis Fisika Outdoor Dengan Menggunakan Modul Kontekstual Untuk Meningkatkan Keterampilan Proses Sains Siswa Pada Materi Fluida Dinamis. Jurnal Wahana Pendidikan Fisika 1 (2013) 66-75 EFEKTIVITAS, 1, 66-75.

Iswatun, I., Mosik, M., \& Subali, B. (2017). Penerapan Model Pembelajaran Inkuiri Terbimbing untuk Meningkatkan KPS dan Hasil Belajar Siswa SMP Kelas VIII Application of Guided Inquiry Learning Model to Improve SPS and Student Learning Outcomes for Junior High School Grade VIII. Jurnal Inovasi Pendidikan IPA, 3(2), 150-160.

https://doi.org/https://doi.org/10.218 31/jipi.v3i2.14871

Juhji. (2016). Peningkatan Keterampilan Proses Sains Siswa Melalui Pendekatan Inkuiri Terbimbing. Jurnal Penelitian Dan Pembelajaran IPA, 2(1), 58-70. https://doi.org/10.30870/jppi.v2i1.41 9

Kali, Y., Levy, K., Levin-peled, R., \& Tal, T. (2018). Supporting outdoor inquiry learning (SOIL): Teachers as designers of mobile-assisted seamless learning. British Journal of Educational Technology, O(0). https://doi.org/10.1111/bjet.12698

Kanfush, P. M. (2014). Dishing Direct Instruction: Teachers and Parents Tell All! The Qualitative Report, 19(1), 1-13. Retrieved from https://nsuworks.nova.edu/tqr/vol19/i ss 1/1/?utm_source=nsuworks.nova.e $\mathrm{du} \% 2 \mathrm{Ftqr} \% 2 \mathrm{Fvol} 19 \% 2 \mathrm{Fiss} 1 \% 2 \mathrm{~F} 1 \&$ utm_medium=PDF\&utm_campaign $=$ PDFCoverPages

Liandari, E., Siahaan, P., Kaniawati, I., \& Isnaini. (2017). Upaya Meningkatkan Kemampuan Merumuskan Dan Menguji Hipotesis Melalui
Pendekatan Keterampilan Proses Sains Dengan Metode Praktikum. Jurnal Wahana Pendidikan Fisika, 2(1), 50-55.

Maradona. (2013). Analisis Ketrampilan Proses Sains Siswa Kelas Xi Ipa Sma Islam Samarinda Pada Pokok Bahasan Hidrolisis Melalui Metode Eksperimen. In Seminar Nasional Kimia 2013. Samarinda: Universitas Mulawarman. Retrieved from http://jurnal.kimia.fmipa.unmul.ac.id /index.php/prosiding/article/view/88

Maulidiyahwarti, G., Sumarmi, \& Amirudin, A. (2016). Pengaruh Model Problem Based Learning Berbasis Outdoor Study Terhadap Hasil Belajar Siswa Kelas XI IIS SMA. Jurnal Pendidikan Teori, Penelitian Dan Pengembangan, 1(2), 94-100.

https://doi.org/http://dx.doi.org/10.17 977/jp.v1i2.6101

Munawaroh, R., \& Setyarsih, W. (2016). Identifikasi Miskonsepsi Siswa dan Penyebabnya pada Materi Alat Optik Menggunakan Three-tier Multiple Choice Diagnostic Test. Jurnal Inovasi Pendidikan Fisika (JIPF) ISSN: 2302-4496 5(2), 79-81.

Mupira, P., \& Ramnarain, U. (2018). The effect of inquiry-based learning on the achievement goal-orientation of grade 10 physical sciences learners at township schools in South Africa. Journal of Research in Science Teaching, 55(6), 1-16. https://doi.org/https://doi.org/10.100 2/tea. 21440

Noor, F. M., \& Wilujeng, I. (2015). Pengembangan SSP Fisika Berbasis Pendekatan CTL Untuk Meningkatkan Keterampilan Proses Sains Dan Motivasi Belajar. Jurnal Inovasi Pendidikan IPA, 1, 73-85. https://doi.org/10.21831/jipi.v1i1.45 34

Prastowo, A. (2013). Pengembangan Bahan Ajar Tematik Panduan 
Lengkap Aplikatif. Jogjakarta: Diva Press. Yogyakarta: Diva Press.

Puji Hartini, R. I. (2017). Penggunaan Levels Of Inquiry Dalam Meningkatkan Keterampilan Proses Sains Siswa. Jurnal Ilmu Pendidikan Fisika, 2(1), 19-24. https://doi.org/10.26737/jipf.v2i1.20 0

Rahmasiwi, A., Santosari, S., \& Sari, D. P. (2015). Peningkatan Keterampilan Proses Sains Siswa dalam Pembelajaran Biologi melalui Penerapan Model Pembelajaran Inkuiri di Kelas XI MIA 9 ( ICT ) SMA Negeri 1 Karanganyar Tahun Pelajaran 2014 / 2015 Improving Student's Science Proces Skill in Biology Throug. Seminar Nasional XII Pendidikan Biologi FKIP UNS 2015, 9, 428-433.

Ratunguri, Y. (2016). Implementasi metode pembelajaran eksperimen untuk meningkatkan keterampilan proses sains mahasiswa pgsd. Jurnal Pedagogia dan Implementasi, 5(2), 137-146.

https://doi.org/10.21070/pedagogia.v $5 \mathrm{i} 2.243$

Remington, T., \& Legge, M. (2016). Outdoor education in rural primary schools in New Zealand: a narrative inquiry. Journal of Adventure Education and Outdoor Learning, 9679(June).

https://doi.org/10.1080/14729679.20 16.1175362

Sari, N., Sunarno, W., \& Sarwanto. (2018). The Analysis Of Students Learning Motivation On Physics Learning In Senior Secondary School. Jurnal Pendidikan Dan Kebudayaan, 3(1), 17-32.

https://doi.org/10.24832/jpnk.v3i1.59 1

Sheftyawan, W. B., Prihandono, T., \& Lesmono, A. D. (2018). Identifikasi Miskonsepsi Siswa Menggunakan Four-Tier Diagnostic Test pada
Materi Optik Geometri. Jurnal Pembelajaran Fisika, 7(2), 147-153. https://doi.org/10.19184/jpf.v7i2.792 1

Subekti, Y., \& Ariswan, A. (2016). Pembelajaran Fisika dengan Metode Eksperimen untuk Meningkatkan Hasil Belajar Kognitif dan Keterampilan Proses Sains The Physics Learning with Experimental Methods to Increase Cognitive Aspects of Learning Outcomes and Science Process Skills. Jurnal Inovasi Pendidikan IPA, 2(2), 252-261. https://doi.org/10.21831/jipi.v2i2.62 78

Sulistiyono, Mundilarto, \& Kuswanto, H. (2017). Pengembangan Panduan Praktikum Fisika Berbasis Inkuiri Untuk Mengembangkan Keterampilan Berpikir Siswa SMA. Jurnal Inovasi Dan Pembelajaran Fisika, 4(1), 89-98. Retrieved from jipf@fkip.unsri.ac.id

Supahar, Rosana, D., Ramadani, M., \& Kurnia Dewi, D. (2017). Performance Assessment Instrument of Science Process Skills Conform The Nature Of Science. Cakrawala Pendidikan, 36(3), 435-445. https://doi.org/10.21831/cp.v36i3.14 731

Suwarna, I. P. (2013). Analisis Miskonsepsi Siswa SMA Kelas X Pada Mata Pelajaran Fisika Melalui CRI (Certain Respon Index) Termodifikasi. Jurnal Laporan Penelitian Universitas Islam Negeri Syarif Hidayatullah. Retrieved from http://repository.uinjkt.ac.id/dspace/b itstream/123456789/24028/3/Jurnal Laporan lemlit Analisis Miskonsepsi \%28iwan permana s\%29.pdf

Wahyuni, S., Indrawati, Sudarti, \& Suana, W. (2017). Developing Science Process Skills And Problem Solving Abilities Based On Outdoor Learning In Junior High School. Jurnal Inovasi Pendidikan IPA, 6(1), 165-169. 
https://doi.org/10.15294/jpii.v6i1.68 49

Widoyoko, E. P. (2014). Penilaian Hasil pembelajaran di Sekolah. Yogyakarta: Pustaka Pelajar.

Wu, P., Jen, T., Kuo, C., Hsu, Y., \& Wu, H. (2018). Learning benefits of secondary school students, inquiryrelated curiosity: A cross-grade ces, curiosity, engagement, and inquiry abilities. Science Education, 102(5), 917-950.

https://doi.org/10.1002/sce.21456 